\title{
Effect of Different Durations of Water-Logging at Different Growth Stages on Seed Yield of Sesame
}

\author{
M. H. Ali ${ }^{1}$ \\ ${ }^{1}$ Agricultural Engineering Division, Bangladesh Institute of Nuclear Agriculture, Bangladesh \\ Correspondence: M. H. Ali, Agricultural Engineering Division, Bangladesh Institute of Nuclear Agriculture, \\ Bangladesh. Tel: 0088-01818-4865-34.
}

Received: November 12, 2018; Accepted: November 27, 2018; Published: December 10, 2018

\begin{abstract}
In Bangladesh, sesame suffers from water-logging during its growing period. Multi-year and multi-location field trials were carried out to study the effect of different durations of water-logging at different growth stages on seed yield of sesame. From two years results, it is revealed that the effects of water-logging during a particular growth stage or particular duration of water-logging on seed yield depends on pre- and/or post water-logging from the rainfall. Differential effects of the cultivars were also observed. The cultivar Binatil-2 and Binatil-3 showed reasonable seed yield under water-logging at flowering and mid pod-formation stages for 24 to 36 hours.
\end{abstract}

Keywords: sesame, water-logging, rainfall, growth stage, yield reduction

\section{Introduction}

Water-logging, drought and salinity stresses are the major adverse environmental conditions that limits plant growth (Dossa et al., 2017; Ali, 2017; Mila et al., 2017). It is reported that sesame is drought tolerant but susceptible to water-logging (Wang et al., 2016). In Indian subcontinent, water-logging threatens the production of sesame (Wei et al., 2013).

Sesame seed oil is a rich source of nutrients. In addition, sesame seeds have many health benefits including ability to improve heart health, lower blood pressure, build strong bones, treat male infertility, and prevent cancer and diabetes (Staughton, 2018).

Sesame is one of the major oilseed crops that is cultivated during the Kharif season (Mid February to June) in Bangladesh. The cultivated area of sesame in Bangladesh is low. The reason is low yield (which is about $0.91 \mathrm{t} / \mathrm{ha}$, national average) (BBS, 2017) and sensitivity of the cultivars to water-logging. To fulfill the national demand of oil, a huge amount of foreign currency is spent to import oil. In order to increase the production of sesame, emphasis should be given to cultivate high yielding varieties applying different modern management practices with special consideration to water-logging (Sarkar et al., 2016; Wang et al., 2016).

Wang et al. (2016) investigated the response of two sesame genotypes to water-logging stress. They imposed 3, 9 and $15 \mathrm{hr}$ water-logging along with $20 \mathrm{hr}$ post-drainage. They found that the water-logging gradually suppressed the expression of sesame genes. Nine hour water-logging was the critical time point, from which response began. Sun et al. (2009) studied the effects of water-logging on leaf protective enzyme activities and yield of sesame. The noted differences among varietal effects - with great effect on the growth rate, withering rate, and death rate at budding and full flowering stages. Hasan et al. (2001) evaluated the growth and yield of a summer grown sesame cultivar for water-logging sensitiveness at different growth stages. The treatments they imposed were $48 \mathrm{hrs}$ waterlogging at early, vegetative, flowering and capsule initiation, and seed filling and ripening stages. They reported that the cultivar was very sensitive to water-logging at crop establishment stage ( $77 \%$ yield reduction) compared to other stages of crop growth (47\% yield reduction). Sarkar et al. (2016) studied the response of two sesame cultivars at 12, 24 and $36 \mathrm{hrs}$ water-logging. The stages investigated were vegetative (2-30 days after sowing) and flowering (55-60 days after sowing). They noted significant response of the cultivars in respect of water-logging and its duration. They observed similar trend of decrease in yield and deterioration of the crop stand for both the cultivars.

In Bangladesh, generally rainfall started from mid April, and heavy rainfall occurs during June-July of the year. But due to global climate change condition, sometimes heavy rainfall started from the beginning of April, which affects on the sesame crop to a great extent. Although new sesame cultivars are adding to the varietal list, their 
performance under changing pattern of rainfall is not tested. The response of sesame to water-logging may vary with cultivars, locations, and time and duration of water-logging.

The objective of this experiment was to study the effect of different durations of water-logging at different growth stages of sesame cultivar on seed yield, with a view to determine the sensitive growth stage(s) to different durations of water-logging and suggest management guidelines.

\section{Materials and Methods}

\subsection{Experimental Site}

Field experiments were carried out at three experimental farm of Bangladesh Institute of Nuclear Agriculture (BINA), covering three agro-ecological zones, namely - Mymensingh $\left(24^{0} 43^{\prime} \mathrm{N}, 90^{\circ} 26^{\prime} \mathrm{E}\right)$, Magura $\left(23^{0} 30^{\prime} \mathrm{N}\right.$, $89^{0} 35^{\prime}$ E) and Ishurdi $\left(24^{\circ} 0^{\prime} \mathrm{N}, 89015^{\prime}\right.$ E). Their positions are shown in Fig.1.

The locations at which experiments were conducted in different years are summarized below:

\begin{tabular}{llll}
\hline Year & Locations & & \\
\hline 2015 & Mymensingh & Ishurdi & - \\
2016 & Mymensingh & - & Magura \\
\hline
\end{tabular}

\subsection{Experimental Design and Treatments}

To avoid complexity in a single experiment (huge treatments, combination of different growth stages and different water-logging durations), two separate experiments were devised. The sowing date was 20th - 23rd March and harvesting date was 9th - 12nd June at different locations and years.

\section{Exp.1. Response of sesame mutants to water-logging (24 hrs) at different growth stages}

The design was RCB with split-plot arrangement, having three replications. Main plot treatments (water-logging) were:

$\mathrm{T}_{1}=$ Control (no water-logging),

$\mathrm{T}_{2}=$ Water-logging at early stage (15 -20 DAS) for 24 hours,

$\mathrm{T}_{3}=$ Water-logging at vegetative stage (30 -35 DAS) for 24 hours,

$\mathrm{T}_{4}=$ Water-logging at early flowering stage (40 -45 DAS) for 24 hours,

$\mathrm{T}_{5}=$ Water-logging at mid pod formation stage (50 -55 DAS) for 24 hours.

The Sub-plot treatments (Variety) were: $\mathrm{V}_{1}=\mathrm{SM}-8, \mathrm{~V}_{2}=\mathrm{SM}-9, \mathrm{~V}_{3}=\mathrm{SM}-067, \mathrm{~V}_{4}=$ Binatil-2, $\mathrm{V}_{5}=$ Binatil-3.

\section{Exp.2. Response of sesame mutants to water-logging for different durations}

The experiment was conducted at BINA HQ, Mymensingh and sub-station, Magura. The design was RCB with splitplot arrangement, having three replications. The main plot treatments (water-logging)were:

$\mathrm{T}_{1}=$ Water-logging at early stage (15-20 DAS) for 18 hours,

$\mathrm{T}_{2}=$ Water-logging at early stage (15-20 DAS) for 36 hours (1.5 days),

$\mathrm{T}_{3}=$ Water-logging at vegetative stage (30-35 DAS) for 18 hours,

$\mathrm{T}_{4}=$ Water-logging at vegetative stage (30-35 DAS) for 36 hours,

$\mathrm{T}_{5}=$ Water-logging at early flowering stage (40-45 DAS) for 18 hours,

$\mathrm{T}_{6}=$ Water-logging at early flowering stage (40-45 DAS) for 36 hours,

$\mathrm{T}_{7}=$ Water-logging at mid pod formation stage (50-55 DAS) for $18 \mathrm{hrs}$,

$\mathrm{T}_{8}=$ Water-logging at mid pod formation stage (50-55 DAS) for 36hrs.

The Sub-plot treatments (Variety) were: $\mathrm{V}_{1}=\mathrm{SM}-8, \mathrm{~V}_{2}=\mathrm{SM}-9, \mathrm{~V}_{3}=\mathrm{SM}-067, \mathrm{~V}_{4}=$ Binatil-2, $\mathrm{V}_{5}=$ Binatil-3.

\subsection{Fertilization and Cultural Practices}

Each plot was fertilized uniformly with basal dose (per hectare basis) of $90 \mathrm{~kg}$ Urea, $140 \mathrm{~kg}$ triple super phosphate, $60 \mathrm{~kg}$ muriate of potash, $100 \mathrm{~kg}$ zypsum, $4 \mathrm{~kg}$ zinc sulphate and $8 \mathrm{~kg}$ Boric Acid. Another $30 \mathrm{kgUrea}$ was applied at active vegetative stage. Weeding and insecticide spray were done according to need. 


\subsection{Statistical Analysis of the Yield Data}

The analysis of variance technique (ANOVA) was carried out on the yield data. The data were analyzed using "STAR" software (of IRRI). The significance of the treatment effect was determined using F-test, and to determine the significant difference among the means of the treatments, least significant difference (LSD) was performed for the 1st experiment (5 treatments) and Tukey's Honest Significant Different (HSD) test was performed for the 2nd experiment ( 8 treatments) (default by the software based on the degree of freedom) at $5 \%$ probability level.

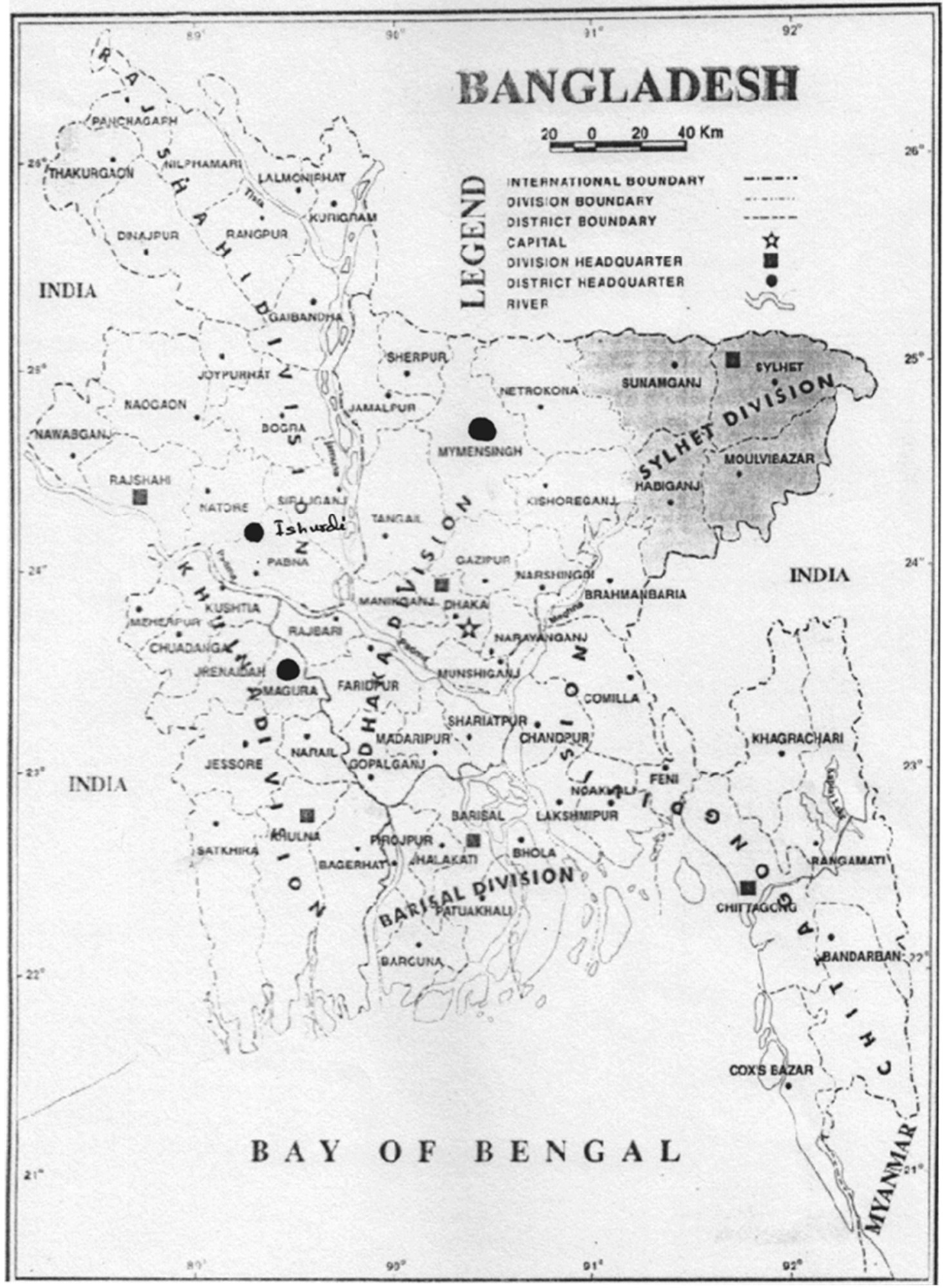

Figure 1. Map of Bangladesh showing the experimental sites ( $\bullet$ Black marked) 


\section{Results and Discussion}

\subsection{Year 2015}

\section{Exp.1. Response of sesame mutants to water-logging (24 hrs) at different growth stages}

The mean seed yield of cultivars (irrespective of treatments) are summarized in Table 1.1The cultivars showed statistically significant differences in yield across both locations. The cultivar V4 produced the highest yield at both the locations. Other cultivars showed variable yield across locations.

The mean seed yield under different water-logging treatments (irrespective of variety) showed insignificant variations (not shown).

Table 1.1 Main effects of sesame cultivars at Mymensingh and Ishwardi under 24 hrs water-logging

\begin{tabular}{lll}
\hline Cultivars & \multicolumn{2}{c}{ Mean seed yield, $\mathrm{kg} \mathrm{ha}^{-1}$} \\
\cline { 2 - 3 } & Ishurdi & Mymensingh \\
\hline $\mathrm{V}_{1}$ & $655 \mathrm{ab}$ & $597 \mathrm{~b}$ \\
$\mathrm{~V}_{2}$ & $673 \mathrm{ab}$ & $568 \mathrm{~b}$ \\
$\mathrm{~V}_{3}$ & $560 \mathrm{c}$ & $630 \mathrm{~b}$ \\
$\mathrm{~V}_{4}$ & $707 \mathrm{a}$ & $773 \mathrm{a}$ \\
$\mathrm{V}_{5}$ & $627 \mathrm{~b}$ & $645 \mathrm{~b}$ \\
\hline
\end{tabular}

Note: Means with the same letter within a column are not significantly different at $5 \%$ level.

\section{Interaction between cultivars and water-logging}

The yield of cultivars under water-logging treatments ( $24 \mathrm{hrs})$ at different growth stages (i.e. interaction effects) are tabulated in Table 1.2. The interaction effects are not statistically different across both locations. The results revealed that the cultivars can produce moderate seed yield under $24 \mathrm{hrs}$ water-logging at any growth stage.

At Mymensingh location, the cultivar V4 produced the highest yield followed by V1 and V3. In general, it seems that water-logging ( $24 \mathrm{hrs}$ ) at early, vegetative, and flowering stages has more detrimental effect on yield compared to water-logging at pod formation stage, except the cultivar V4.

At Ishurdi location, the cultivar V4 produced the highest seed yield followed by V2. Here, no effect of growth stage is noticeable (as that of Mymensingh). This may be due to the variation of rainfall at pre-treatment and posttreatment (Fig.2).

Table 1.2 Yield of cultivars under different treatments

\begin{tabular}{lllllll}
\hline & Treat- & & \multicolumn{5}{c}{ Seed yield, $\mathrm{kg} \mathrm{ha}^{-1}$} \\
ment & V1 =SM-8 & V2 =SM-9 & V3= SM-067 & V4= Binatil-2 & V5= Binatil-3 \\
\hline \multirow{3}{*}{ Mymensingh } & T1 & 819 & 776 & 771 & 896 & 736 \\
& T2 & 524 & 440 & 569 & 825 & 558 \\
& T3 & 574 & 531 & 611 & 719 & 535 \\
& T4 & 427 & 546 & 530 & 716 & 681 \\
& T5 & 638 & 545 & 666 & 706 & 715 \\
& F-test (5\%) & NS & NS & NS & NS & NS \\
\hline \multirow{3}{*}{ Ishwardi } & T1 & 615 & 675 & 574 & 768 & 647 \\
& T2 & 612 & 652 & 470 & 746 & 590 \\
& T3 & 709 & 786 & 668 & 796 & 634 \\
& T4 & 749 & 632 & 550 & 601 & 601 \\
& T5 & 587 & 618 & 538 & 622 & 661 \\
& F-test (5\%) & NS & NS & NS & NS & NS \\
\hline
\end{tabular}

\section{Exp.2. Response of sesame mutants to water-logging for different durations (2014-15)}

The mean seed yield of cultivars (irrespective of treatments) summarized in Table 2.1Sesame cultivars showed significant difference at Ishurdi, but not at Mymensingh. At Ishurdi, the highest seed yield was produced by the 
cultivar V2, which is statistically similar to V4 and V5. At Mymensingh, all the cultivars produced statistically similar yield.

The mean seed yield under different water-logging treatments (irrespective of variety) showed insignificant variations (not shown).

\section{Interaction between Cultivars and Water-Logging}

Yield of cultivars under different water-logging treatments (i.e. interaction effects) are tabulated in Table 2.2. The interaction effects are not statistically different at both the locations. At Mymensingh, water-logging at flowering stage for 36 hrs (T6) showed the most detrimental effect on yield, which may be due to coincides of natural rainfall with the artificial water-logging (Fig.2).

At Ishurdi, overall, the cultivar V4 produced the highest yield. Here, no such detrimental effect of a specific treatment, similar to that of Mymensingh, is visible.

Results revealed that the cultivars can produce moderate seed yield up to 36 hours water-logging condition at any growth stage, if pre- and/or post-period of the water-logging are not adjunct with heavy rainfall. The difference in yield between two locations may be due to variation in climatic (mainly rainfall variation) and soil conditions.

Table 2.1 Mean seed yield of cultivars (irrespective of treatments)

\begin{tabular}{lll}
\hline Cultivars & \multicolumn{2}{l}{ Mean seed yield,kg ha ${ }^{-1}$} \\
\cline { 2 - 3 } & Ishurdi & Mymensingh \\
\cline { 2 - 3 } V1= SM-8 & $669 \mathrm{~b}$ & $606 \mathrm{a}$ \\
V2= SM-9 & $741 \mathrm{a}$ & $602 \mathrm{a}$ \\
V3= SM-067 & $682 \mathrm{~b}$ & $637 \mathrm{a}$ \\
V4 Binatil-2 (Check) & $740 \mathrm{a}$ & $626 \mathrm{a}$ \\
V5= Binatil-3 (Check) & $706 \mathrm{ab}$ & $604 \mathrm{a}$ \\
\hline
\end{tabular}

Note: Means with the same letter within a column are not significantly different at $5 \%$ level.

Table 2.2 Effect of treatments on sesame yield at each level of cultivars

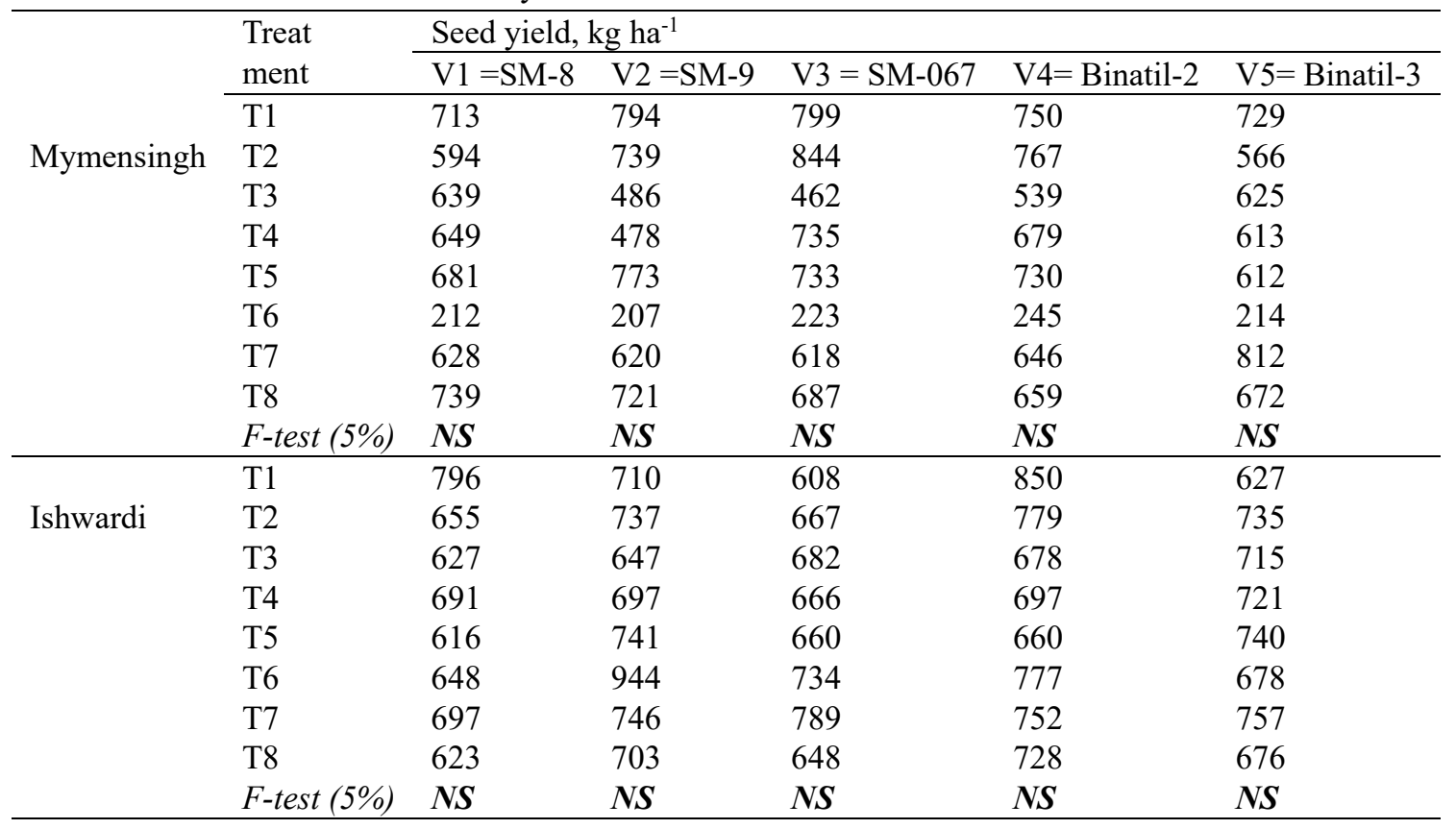



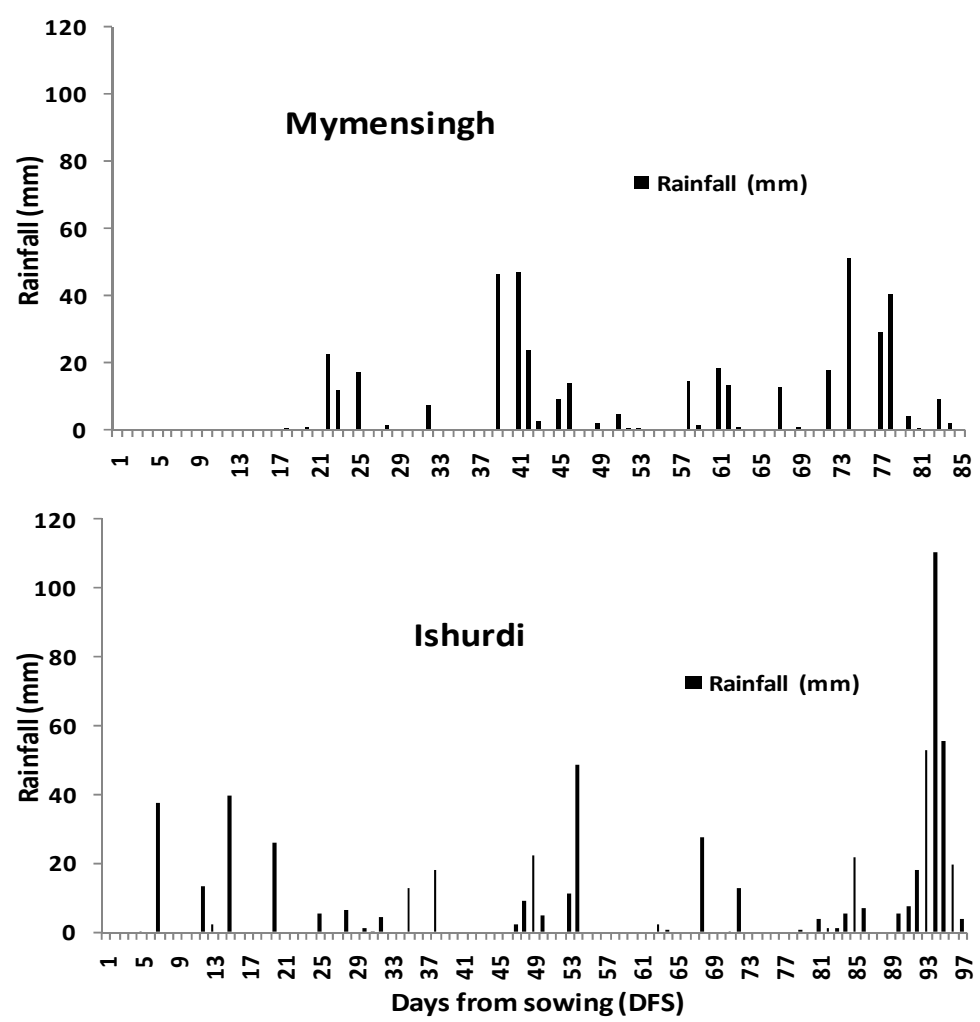

Figure2.Rainfall distribution throughout the growing period (2015)

\subsection{Year2016 (2015-16)}

\section{Experiment-1. Response of sesame mutants to water-logging at different growth stages}

Mean seed yields under different treatments are summarized in Table 3.1. The water-logging treatments showed significant difference for yield at Magura, but not at Mymensingh. Water-logging at vegetative and early stages showed higher reduction in yield, and the mid pod formation showed the least reduction. Overall, the yield at Magura was higher compared to that of Mymensingh. This may be due to the differential rainfall pattern between the locations.

Table 3.1 Mean yield of sesame under different treatments

\begin{tabular}{lll}
\hline Treatments & \multicolumn{2}{l}{ Mean seed yield, t ha } \\
\cline { 2 - 3 } & Magura & Mymensingh \\
\cline { 2 - 3 } $\mathrm{T}_{1}$ & $1.63 \mathrm{a}$ & 1.51 \\
$\mathrm{~T}_{2}$ & $1.40 \mathrm{bc}$ & 1.49 \\
$\mathrm{~T}_{3}$ & $1.21 \mathrm{c}$ & 1.15 \\
$\mathrm{~T}_{4}$ & $1.54 \mathrm{ab}$ & 1.16 \\
$\mathrm{~T}_{5}$ & $1.62 \mathrm{a}$ & 1.48 \\
F-test (5\%) & & NS \\
\hline
\end{tabular}

Means with the same letter within a column are not significantly different at $5 \%$ level by LSD.

\section{Interaction Effects}

The yield of cultivars under different water-logging treatments (i.e. interaction effects) are tabulated in Table 3.2. The interaction effects are not statistically different at both the locations. At Mymensngh, in general, the cultivars $\mathrm{V} 4, \mathrm{~V} 5$, and V1 performed better than the others. The treatments T3 and T4, i.e. water-logging at vegetative and flowering stages showed higher reduction in yield compared to other treatments.

At Magura, the yields are almost similar for all cultivars. In case of cultivar V3, water-logging at early stage showed higher reduction. All cultivars showed lower yield due to water-logging at vegetative stage. 
There was marked variation of rainfall amount and its distribution between the locations (Fig.3), which may affect to the yield reduction between the locations.

Table 3.2 Effect of treatments on sesame yield at each level of cultivars

\begin{tabular}{lllllll}
\hline \multirow{5}{*}{ Mymensingh } & Treat- & \multicolumn{5}{c}{ Seed yield, tha ${ }^{-1}$} \\
\cline { 2 - 7 } & ment & V1 $=$ SM-8 & V2 $=$ SM-9 & V3 $=$ SM-067 & V4= Binatil-2 & V5= Binatil-3 \\
\cline { 2 - 7 } & T2 & 1.52 & 1.46 & 1.32 & 1.65 & 1.59 \\
& T3 & 1.50 & 1.44 & 1.44 & 1.61 & 1.47 \\
& T4 & 1.19 & 1.02 & 1.11 & 1.19 & 1.28 \\
& T5 & 1.53 & 1.06 & 1.28 & 1.15 & 1.25 \\
& F-test (5\%) & NS & NS & NS & NS & NS \\
\hline \multirow{5}{*}{ Magura } & T1 & 1.75 & 1.66 & 1.60 & 1.59 & 1.54 \\
& T2 & 1.33 & 1.38 & 1.08 & 1.48 & 1.70 \\
& T3 & 1.21 & 1.17 & 1.17 & 1.24 & 1.26 \\
& T4 & 1.45 & 1.45 & 1.30 & 1.91 & 1.60 \\
& T5 & 1.76 & 1.70 & 1.50 & 1.58 & 1.57 \\
& F-test (5\%) & NS & NS & NS & NS & NS \\
\hline
\end{tabular}

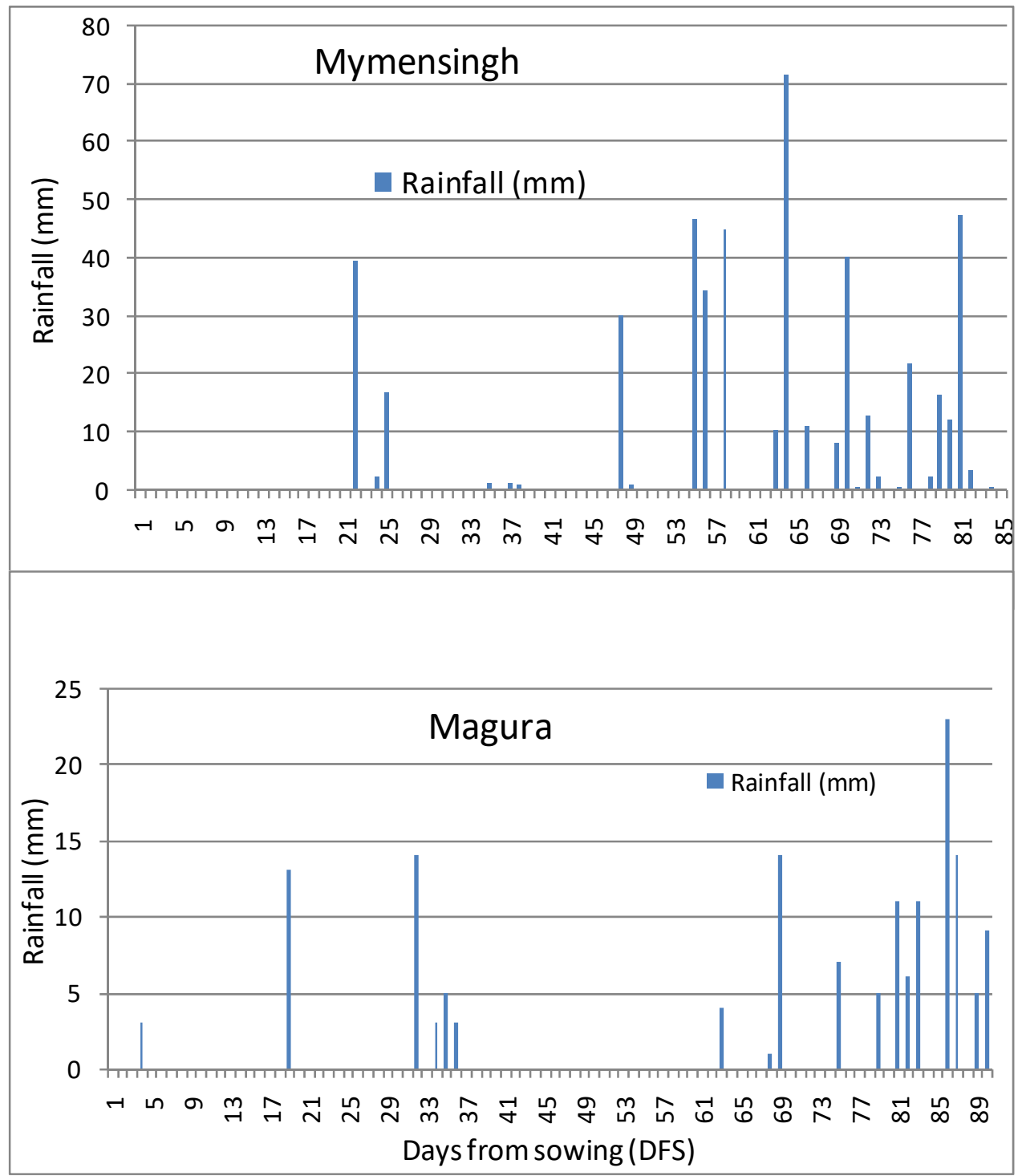

Figure 3. Rainfall distribution at Mymensingh and Magura during crop period (2016) 


\section{Experiment-2. Response of sesame mutants to water-logging for different durations}

The mean seed yields under different treatments (irrespective of cultivars) are summarized in Table 4.1. The waterlogging treatments showed significant difference in yield both at Magura and Mymensingh. Water-logging at vegetative stage (for both 18 and $36 \mathrm{hrs)} \mathrm{showed} \mathrm{higher} \mathrm{reduction} \mathrm{in} \mathrm{yield.} \mathrm{Due} \mathrm{to} \mathrm{water-logging} \mathrm{at} \mathrm{early} \mathrm{stage,}$ some plants recovered (or re-generated) to some extent, and thus compensated in seed yield. Water-logging at flowering stage $36 \mathrm{hrs}$ showed third highest yield reduction.

The mean seed yields under different cultivars are not statistically different (not shown).

Table 4.1 Mean seed yield of sesame under different treatments

\begin{tabular}{lll}
\hline Treatments & \multicolumn{2}{l}{ Mean seed yield, t ha } \\
\cline { 2 - 3 } & Magura & Mymensingh \\
\cline { 2 - 3 } $\mathrm{T}_{1}$ & $1.49 \mathrm{ab}$ & $1.91 \mathrm{a}$ \\
$\mathrm{T}_{2}$ & $1.35 \mathrm{ab}$ & $1.42 \mathrm{ab}$ \\
$\mathrm{T}_{3}$ & $0.97 \mathrm{a}$ & $1.31 \mathrm{ab}$ \\
$\mathrm{T}_{4}$ & $0.71 \mathrm{~b}$ & $1.18 \mathrm{~b}$ \\
$\mathrm{~T}_{5}$ & $1.57 \mathrm{a}$ & $1.36 \mathrm{ab}$ \\
$\mathrm{T}_{6}$ & $1.39 \mathrm{ab}$ & $1.29 \mathrm{ab}$ \\
$\mathrm{T}_{7}$ & $1.59 \mathrm{a}$ & $1.62 \mathrm{ab}$ \\
$\mathrm{T}_{8}$ & $1.56 \mathrm{a}$ & $1.56 \mathrm{ab}$ \\
F-test (5\%) & & \\
\hline
\end{tabular}

Means with the same letter within a column are not significantly different at $5 \%$ level by Tukey's Honest Significant Difference (THSD) test.

\section{Interaction Effect}

The seed yields of different cultivars under different water-logging treatments (Interaction effects) are summarized in Table 4.2. The interaction effects are not significant at 5\% level of probability. At Mymensingh, although variations are not significant, water-logging at vegetative stage (T3 and T4) showed the highest yield reduction, followed by water-logging at flowering stage (T5 and T6). Similar trends are also observed at Magura. Sarkar et al. (2016) also observed 51-58\% yield reduction for $36 \mathrm{hrs}$ water-logging at vegetative and flowering stage.

Table 4.2 Effect of treatments on sesame yield at each level of cultivars

\begin{tabular}{|c|c|c|c|c|c|c|}
\hline \multirow[t]{2}{*}{ Location } & \multirow[t]{2}{*}{ Treatment } & \multicolumn{5}{|c|}{ Seed yield, $\mathrm{t} \mathrm{ha}^{-1}$} \\
\hline & & $\mathrm{V} 1=\mathrm{SM}-8$ & $\mathrm{~V} 2=\mathrm{SM}-9$ & $\mathrm{V3}=\mathrm{SM}-067$ & V4= Binatil-2 & $\mathrm{V} 5=$ Binatil-3 \\
\hline \multirow{9}{*}{ Mymensingh } & $\mathrm{T} 1$ & 1.91 & 1.86 & 1.85 & 1.95 & 1.98 \\
\hline & $\mathrm{T} 2$ & 1.54 & 1.52 & 1.11 & 1.33 & 1.61 \\
\hline & $\mathrm{T} 3$ & 1.18 & 1.18 & 1.06 & 1.65 & 1.47 \\
\hline & $\mathrm{T} 4$ & 0.98 & 1.32 & 1.04 & 1.30 & 1.26 \\
\hline & T5 & 1.32 & 1.36 & 1.18 & 1.50 & 1.46 \\
\hline & $\mathrm{T} 6$ & 1.30 & 1.35 & 1.13 & 1.48 & 1.19 \\
\hline & $\mathrm{T} 7$ & 1.67 & 1.71 & 1.44 & 1.59 & 1.71 \\
\hline & $\mathrm{T} 8$ & 1.49 & 1.67 & 1.40 & 1.60 & 1.62 \\
\hline & $F$-test (5\%) & $N S$ & $N S$ & $N S$ & $N S$ & $N S$ \\
\hline \multirow{9}{*}{ Magura } & $\mathrm{T} 1$ & 1.75 & 1.70 & 1.35 & 1.53 & 1.10 \\
\hline & $\mathrm{T} 2$ & 1.11 & 1.40 & 1.19 & 1.48 & 1.58 \\
\hline & $\mathrm{T} 3$ & 1.20 & 1.02 & 0.83 & 0.81 & 0.99 \\
\hline & $\mathrm{T} 4$ & 0.61 & 0.69 & 0.59 & 0.71 & 0.93 \\
\hline & T5 & 1.73 & 1.72 & 1.61 & 1.39 & 1.39 \\
\hline & $\mathrm{T} 6$ & 1.16 & 1.44 & 1.27 & 1.64 & 1.44 \\
\hline & $\mathrm{T} 7$ & 2.04 & 1.35 & 1.53 & 1.59 & 1.46 \\
\hline & $\mathrm{T} 8$ & 1.39 & 1.48 & 1.60 & 1.81 & 1.54 \\
\hline & $F$-test $(5 \%)$ & $N S$ & $N S$ & $N S$ & $N S$ & $N S$ \\
\hline
\end{tabular}




\section{Conclusion}

Water-logging threatens sesame production in Bangladesh and elsewhere. From the multi-year and multilocational studies, the following conclusions can be drawn:

- Effects of water-logging during a particular growth stage or particular duration on sesame yield depends on pre- and/or post water-logging from the rainfall.

- Binatil-2 and Binatil-3 showed good seed yield (1.5-1.6 t/ha) under water-logging at flowering and mid pod-formation stages for 24- $36 \mathrm{hrs}$.

- The mutants SM-8 and SM-9 produces moderate seed yield (1.1-1.3 t/ha) under 24-36 hrs water-logging

\section{References} at early and pod-formation stages.

Ali, M. H. (2017). Saline irrigation-water management strategy in wheat cultivation for higher yield and water productivity. International Journal of Engineering Research and Management (IJERM), 4(6), 25-32.

Aslam, M., Nasrullah, H. M., Akhtar, M., Ali, B., Akram, M., Nawaz, H., \& Javeed, H. M. R. (2015). Role of different planting techniques in improving the water logging tolerance and productivity of sesame (Sesamumindicum L.). Bangladesh Journal of Scientific and Industrial Research, 50(3), 193-198. https://doi.org/10.3329/bjsir.v50i3.25585

BBS (Bangladesh Bureau of Statistics). (2017). Agricultural Statistical Yearbook of Bangladesh. Ministry of Planning, the Peoples Republic of Bangladesh, pp. 121-122

Dossa, K., Li, D., Wang, L., Zheng, X., Yu, J., Wei, X., Fonceka, D., Diouf, D., Liao, B., Cisse, N., \& Zhang, X. (2017). Dynamic transcriptome landscape of sesame (SesamumIndicum L.) under progressive drought and after rewatering. Genomic Data, 11, 122-124. https://doi.org/10.1371/journal.pone.0149912

Hassan, A. A., Karim,N. N., Sarkar, A. A., \& Ali, M. H. (2001). Effect of water logging on the growth and yield of summer grown sesame (Sesanumindicum). Ind. J. of Agril. Sci., 71(4), 271-272.

Mila, A. J., Ali, M. H., Akanda, A. R., Rashid, M. H., \& Rahman, M. A. (2017). Effects of deficit irrigation on yield, water productivity and economic return of sunflower. Cogent Food \& Agriculture, 3, 1287619. https://doi.org/10.1080/23311932.2017.1287619

Sarkar, P. K., Khatun, A., \& Singha, A. (2016). Effect of duration of water-logging on crop stand and yield of sesame. Int. J. of Innovation and Applied Studies. Int. J. of Innovation and Applied Studies, 14(1), 1-6.

Sun, J., Zhang, X., Zhang, Y., \& Huang, B. (2009). Effects of Waterlogging on Leaf Protective Enzyme Activities and Seed Yield of Sesame at Different Growth Stages. Chinese Journal of Applied and Environmental Biology, 2009(6), 790-795. https://doi.org/10.3724/SP.J.1145.2009.00790

Wang L., Li, D., Zhang, Y., Gao, Y., Yu, J., Wei, X., \& Zhang, X. (2016).Tolerant and Susceptible Sesame Genotypes Reveal Waterlogging Stress Response Patterns. PLOS Journal, March(2). https://doi.org/10.1371/journal.pone.0149912

Wei, W.,Wang, L., Ding, X., Zhang, Y., Gao, Y., \& Zhang, X. (2013). Morpho-anatomicaland physiological responses to waterlogging of sesame (Sesamumindicum L.). Plant Science, 208(July 2013), 102-111. https://doi.org/10.1016/j.plantsci.2013.03.014

\section{Copyrights}

Copyright for this article is retained by the author(s), with first publication rights granted to the journal.

This is an open-access article distributed under the terms and conditions of the Creative Commons Attribution license (http://creativecommons.org/licenses/by/4.0/). 